\title{
What Were They Thinking? Insider Trading and the Scienter Requirement
}

Donald C. Langevoort

Georgetown University Law Center, langevdc@law.georgetown.edu

Georgetown Public Law and Legal Theory Research Paper No. 12-111

This paper can be downloaded free of charge from:

https://scholarship.law.georgetown.edu/facpub/989

http://ssrn.com/abstract=2120141

Donald C Langevoort, What Were They Thinking? Insider Trading and the Scienter Requirement, in RESEARCH HANDBOOK ON INSIDER TRADING (Stephen Bainbridge, ed., Edward Elgar Publishing Ltd. forthcoming)

This open-access article is brought to you by the Georgetown Law Library. Posted with permission of the author. Follow this and additional works at: https://scholarship.law.georgetown.edu/facpub

Part of the Business Law, Public Responsibility, and Ethics Commons, Business Organizations Law Commons, and the Securities Law Commons 
What were they thinking? Insider trading and the scienter requirement

Donald C. Langevoort

On its face, the connection between insider trading regulation and the state of mind of the trader or tipper seems fairly intuitive. Insider trading is a form of market abuse: taking advantage of a material, non-public secret to which one is not entitled, generally in breach of some kind of fiduciary-like duty. It is an exploitation of status or access, typically coupled with some form of faithlessness. Certainly the extraordinary public attention that insider trading enforcement and prosecutions command reflects the idea that the essence of unlawful insider trading is cheating. These prosecutions are main-stage morality plays, with greed as the story line. ${ }^{1}$ The SEC in particular seems to sense that it garners public political support by casting itself in the role of tormentor of the greedy.

If this is right, then what the legal system should be looking to proscribe is deliberate exploitation - trading on the basis of information in order to gain an unfair, unlawful advantage over others in the marketplace. That involves a fairly tight causal connection between knowledge of the information and the decision to buy or sell.

This Chapter will examine both the law and the psychology associated with this pursuit. The USA law of insider trading is actually much more conflicted and confusing as to the necessary state of mind for either trading or tipping. ${ }^{2}$ Mostly, this is a product of conceptual

\footnotetext{
${ }^{1}$ See Donald C. Langevoort, Rereading Cady Roberts: The Ideology and Practice of
} Insider Trading Regulation, 99 Colum. L. Rev. 1319 (1999). 
confusion in how we define unlawful insider trading - the quixotic effort to build a coherent theory of insider trading by reference to the law of fraud, rather than a more expansive market abuse standard. It is familiar enough that the courts (at the SEC's urging) have taken dominion of the law of insider trading by deeming it a species of fraud. That is intellectually awkward because there is relatively little about unlawful insider trading that can fairly be considered deceptive, yet deception is the essence of fraud. The result is a crazy-quilt of made-up doctrinal innovations to declare abusive trading fraudulent, either vis-à-vis other marketplace traders (the affirmative duty to disclose when there is a pre-existing duty of trust) or the source of the information (misappropriation by feigning loyalty to the entrustor). Another layer of complication ensues when the subject of the prosecution didn't trade but instead gave the information to someone else, so that we have to ask why this communication occurred. Given this patchwork, it actually becomes very difficult to describe the legally required state of mind for insider trading prosecutions.

But there is also an interesting psychological question. What actually is going through the mind of the alleged trader or tipper? Is it always simple greed? Or can there be an element of

${ }^{2}$ This issue is well explored in the literature. See, e.g., Allan Horwich, Possession versus Use: Is there a Causation Element in the Prohibition on Insider Trading?, 52 Bus. Law. 1235 (1997); Donna M. Nagy, The Possession versus Use Debate in the Context of Trading by Traditional Insiders: Why Silence Can Never be Golden, 67 U. Cinn. L. Rev. 1129 (2009). For a lengthier exposition of the doctrinal issues discussed here, see Donald C. Langevoort, Insider Trading: Regulation, Enforcement and Prevention 3:13-.14 (2012 ed.). 
unconscious perception — or rationalization — at work. Given the complexity and occasional arbitrariness of the law, what role might this indeterminacy play in trading decisions? My sense is that the motivations and causal explanations for what is charged as insider trading are often quite murky and not easily explained by pure greed. The poster example for the "what were they thinking" question is Martha Stewart, an extraordinarily savvy and successful businesswoman who went to jail for a cover-up after being accused of selling stock to avoid a loss of less than $\$ 50,000$, a tiny fraction of her net wealth. ${ }^{3}$ This Chapter will try to connect the law of insider trading to a more sophisticated approach to state of mind, motivation, and causation.

I. The surprisingly hard doctrinal issues in assessing state of mind for insider trading

One of the necessary consequences of treating insider trading as fraud is a requirement of scienter. The Supreme Court has insisted that the statutory authorization for the main antifraud prohibition in the securities laws $\_\S 10(\mathrm{~b})$ of the Securities Exchange Act and Rule 10b-5 thereunder - requires intentionality, something more than negligence. ${ }^{4}$ But what intentionality means generally remains contested, with the main question being whether some form of recklessness can suffice. The prevailing view in the lower courts is yes, though most insist that

\footnotetext{
${ }^{3}$ See infra notes 43-44 and accompanying text.

${ }^{4}$ Ernst \& Ernst v. Hochfelder, 425 U.S. 185 (1976). Although such a requirement might not be evident from the text of Rule 10b-5, the Supreme Court considered it implicit in the underlying statutory authorization in $\S 10(\mathrm{~b})$.
} 
the recklessness must have a subjective dimension to it, something akin to conscious or deliberate avoidance of the truth. ${ }^{5}$

Mapping this onto the law of insider trading has been difficult. As noted at the outset of this Chapter, the intuitive characterization with respect to trading (putting aside tipping for the moment) is that scienter means that the insider must have deliberately taken advantage of - that is, used - the information for personal gain. Use implies a causal connection between the information and the trade, which if broken negates the intentionality of the allegedly bad act. By and large, the case law invokes the use locution, often referring to the essence of insider trading intentionality as trading "on the basis of" the information in question. ${ }^{6}$

Hence it is not surprising that cases have arisen where the defendant concedes (at least arguendo) that he came into possession of information that can be characterized as both material and nonpublic but that this was not the reason that he bought or sold. Rather, there was an entirely independent causal explanation for the trade, i.e., that he would have traded anyway, at the same time and in the same amount, even without access to the information. Perhaps the best known example of this in the case law is a director-defendant who sold a sizable amount of his company's stock after receiving disappointing news about the company's financial condition during a board meeting. ${ }^{7}$ His defense was that he had already made plans to sell that stock in

${ }^{5}$ For a discussion of the case law, see James D. Cox et al., Securities Regulation: Cases and Materials 671-74 (6 $6^{\text {th }}$ ed. 2009).

${ }^{6}$ E.g., Dirks v. SEC, 463 U.S. 646 (1983). Dirks read into the law a personal benefit requirement for purposes of the law of "tipping," which strongly implies misuse. Id. At 662-64.

${ }^{7}$ See SEC v. Adler, 137 F.3d 1325 (11 ${ }^{\text {th }}$ Cir. 1998). 
order to buy a large truck for his son, who was going into the transport business, so that there was no causal connection between what he might have learned at the meeting and the subsequent sale.

Following from the intuition that insider trading is about the misuse of information, the court agreed that such a defense can properly be raised. To be sure, the court was extremely skeptical of the defense as a factual matter, and so held that a presumption of misuse was warranted that the defendant would then have the burden of rebutting. Some other cases, particularly criminal prosecutions, have articulated the same causation standard without any such presumption, thus apparently allocating to the prosecution the burden of proving causation. ${ }^{8}$

That gets us into the mind of the alleged insider trader, which is inevitably very difficult. Some of the practical burden, however, is ameliorated by the fact that this form of subjective intent can be proven circumstantially_fact-finders are entitled to draw inferences about causation from the surrounding facts. As we shall see later on, this introduces a great deal of creative freedom for judges or juries to tell a story of their own making in characterizing the defendant's state of mind. So, we shouldn't overstate any burden that this way of reading the law puts on prosecutors or the SEC, so long as they can persuade the fact-finder of the defendant's greedy character or disposition. ${ }^{9}$

${ }^{8}$ See United States v. Smith, 155 F.3d 1051 ( $9^{\text {th }}$ Cir. 1998); SEC v. Talbot, 430 F. Supp.2d 1029 (C.D. Cal. 2006).

${ }^{9}$ Most cases articulating a "use" requirement end up finding the standard met. E.g., United States v. Henke, 222 F.3d 633 ( $9^{\text {th }}$ Cir. 2000). 
But this approach to scienter in insider trading cases has been contested, and by no means represents a clear statement of prevailing law. The SEC has long rejected the view that causation has any proper role to play: that all that is necessary is that the trader was aware of the information in question, which is often referred to as a "possession" test ${ }^{10}$. Hence the split among the courts is referred to as the "possession versus use" debate, and is controversial in discussions about insider trading law outside the United States as well. ${ }^{11}$

There are numerous arguments in favor of a possession standard. Some are simply pragmatic - that searching for causation inside the mind of the trader is subject to too much confusion and potential error, and so not worth the effort. The leading court favoring a possession standard has said, in dicta:

Because the advantage is in the form of information, it exists only in the mind of the trader. Unlike a loaded weapon, which may stand ready but unused, information cannot lay idle in the human brain. The individual with such information may decide to trade upon that information, to alter a previously decided-upon transaction, to continue with a previously planned transaction even though publicly available information would

${ }^{10}$ In re Sterling Drug Inc., 14 S.E.C. Docket 824 (1978). This was not always so: see In re Investors Mgt. Co., 44 S.E.C. 633 (1971). Investors Management involved a possession versus use issue beyond the scope of my Chapter: how the scienter standard applies to institutional trading, where there might be a separation of personnel between those who might know a fact, and those who determine purchases and sales.

${ }^{11}$ See Hui Huang, The Insider Trading "Possession versus Use" Debate: An International Analysis, 34 Sec. Reg. L.J. 130 (2006). 
now suggest otherwise, or simply do nothing. ... As a matter of policy, then, a requirement of a causal connection between the information and a trade could frustrate attempts to distinguish between legitimate trades and those conducted in connection with insider trading. ${ }^{12}$

On a more conceptual level, there is also the point that causation is about motivation, which is generally said not to be crucial to a scienter inquiry in Rule $10 \mathrm{~b}-5$ cases. It usually doesn't matter why the defendant lied (indeed, there may be good reasons to do so) but simply that he was aware of the truth at the time he uttered the falsity. Moreover, the idea that recklessness suffices for scienter strongly suggests that knowingly taking advantage of the information is not the only way to satisfy the state of mind requirement—recklessness comports better with possession than use. Finally, there is a fiduciary duty-based justification—fiduciaries are obliged to reveal material information known to be in their possession without any requirement that they be trying to gain from it. That latter point, however, may once again mainly show the awkwardness of trying to import so much prophylactic fiduciary duty thinking into a deception-oriented antifraud regime.

The SEC did not stay idle as this split among the courts became clear. In 2000, the Commission sought to resolve the dispute by adopting Rule 10b5-1, which articulates the law of insider trading in terms of a prohibition on trading "on the basis of" inside information, but then defines "on the basis of" as simple awareness as per the possession test. The SEC described

${ }^{12}$ United States v. Teicher, 987 F.2d 112 (2d Cir. 1993). For a more recent decision, see United States v. Royer, 549 F.3d 886 (2d Cir. 2008). 
awareness in familiar terms_- "having knowledge; conscious; cognizant."13 Somewhat surprisingly, this attempted codification of the possession standard has not been entirely effective. While some courts have taken it into account as authoritative, others seem to ignore Rule 10b5-1 and stick to the idea that causation remains the controlling requirement, albeit perhaps with a presumption of use. ${ }^{14}$ Possibly, this is based on the sense that scienter is embedded in the statutory rulemaking authorization in $\S 10(\mathrm{~b})$, over which the Commission has limited power of modification. Indeed, there have been serious claims that Rule 10b5-1, in this one respect, was beyond the SEC's rulemaking authority. ${ }^{15}$

Again, we shouldn't overstate the practical importance of all this, given the permissibility (indeed inevitability) of circumstantial proof of misuse. In fact, there is often a reversal of direction in circumstantial proof when the defendant denies any knowledge of the information whatsoever. Under those circumstances, courts generally permit the SEC or prosecutor to try to show possession circumstantially by offering evidence of misuse (e.g, patterns of behavior that are explainable only in terms of an effort by the defendant to take advantage of the information,

${ }^{13}$ See Securities Act Release 7881, Aug. 15, 2000.

${ }^{14}$ E.g., United States v. Anderson, 533 F.3d 623 ( $8^{\text {th }}$ Cir. 2008); SEC v. Bauer, 2011 WL 2115924 (E.D. Wis. 2011).

${ }^{15}$ See United States v. Nacchio, 519 F.3d 1140, $1167-69$ (10 ${ }^{\text {th }}$ Cir. 2008); see also Carol Swanson, Insider Trading Madness: Rule 10b5-1 and the Death of Scienter, 52 U. Kan. L. Rev. 147 (2003). 
such as the very short time between learning it and trading, or trading in particularly large amounts vis-à-vis normal investing patterns). ${ }^{16}$

So this is one place in the law where we seek to inquire into the "why" behind the choice to buy or sell when there is an allegation of insider trading. There are other places, however. One - which has not received as much judicial or academic commentary as it should — has to do with what we mean by awareness when there are doubts about either the materiality or public nature of the information. ${ }^{17}$ In other words, is it important (or essential) that the defendant appreciate that what is in his possession would be significant to other investors, or was unavailable to them. Materiality is one of the hardest fact determinations in the securities laws, an effort to distinguish the unimportant from the significant. Implicitly, the "use" test takes care of this by assuring that the information at least motivated the defendant's trade; the "possession" test does not so insist, and so raises the possibility that information might objectively be material — or at least so judged by the fact-finder — without the defendant actually realizing that it was significant. The same could occur where the defendant didn't fully appreciate the secrecy of the information. That is entirely plausible in cases where information may have found its way into the public domain, by leaks or other informal means, even though there has been no public announcement. Here, too, the law can be quite murky. Some courts say that broad general

${ }^{16}$ E.g., SEC v. Roszak, 495 F. Supp.2d 875, 890 (N.D. Ill. 2007).

${ }^{17}$ See Langevoort, supra note 2, at 5:5; Allan Horwich, The Neglected Relationship of Materiality and Recklessness in Actions Under Rule 10b-5, 55 Bus. Law. 1023 (2000). 
dissemination is necessary before information becomes public, while other suggest that enough leakage will suffice. ${ }^{18}$

The final place where state of mind questions become challenging is in the law of tipping. The Supreme Court has allowed insider trading cases to go forward against an insider who does not trade but instead passes on the information to someone else. ${ }^{19}$ But to restrain liability for otherwise legitimate communications, the Court — at least for classical insider trading cases_insisted on proof that the insider was breaching a fiduciary duty for personal benefit by passing on the information, and that the recipient knew or had reason to know of the self-serving breach. That once again takes us inside the mind of the insider, this time to check for selfish motivation. This is made partly easier by the extraordinarily capacious definition of personal benefit offered by the Court. The requisite personal benefit need not be pecuniary (e.g, a kick-back from the recipient), but can consist of a reputational gain or even the warm glow from making a gift of the information to a family member or friend. We have to check the mind of the recipient as well, to see if there was enough awareness or suspicion that selfishness was at work in motivating the insider's tip. Many cases offer particularly vexing problems here, especially when there is a chain of tippers and tippees - the situation where the insider tells a friend, who tells some other acquaintances, and so on. ${ }^{20}$

As with the other state of mind subjects we have surveyed, there is some doctrinal inconsistency here, too. Insider trading cases take one of two basic forms, classical or

\footnotetext{
${ }^{18}$ See Langevoort, supra note 2 , at 5:4.

${ }^{19}$ See Dirks v. SEC, 463 U.S. 646 (1983).

${ }^{20}$ See Langevoort, supra note 2 , at 4:10-.11.
} 
“misappropriation." The test just described clearly applies in classical cases, but not necessarily when the allegation is that the insider-tipper defrauded the source of the information by giving it to someone else. While most of the time the selfish (broadly defined) motivation for the tip is obvious enough, the SEC and a few courts have said that it is not essential as part of the prosecution. ${ }^{21}$ The point seems to be that it is possible to have a purely reckless tip, where the tipper supposedly misappropriates by passing on the information to someone who trades not to facilitate that trading but with indifference to the likelihood that that would happen.

What characterizes each of these doctrinal questions is the necessity for the fact-finder to enter the mind of the accused insider trader or tipper to draw some kind of inference about causation and/or motivation. As we shall see in the next part of this Chapter, that is laden with difficulty. Separately, note the doctrinal confusion in and of itself - often it is impossible to say with any degree of confidence whether a particular instance of trading is lawful or not. That indeterminacy has its own psychological consequences, as we shall also see.

\section{Explaining insider trading}

The aim of this second part is to offer a taxonomy of "state of mind" explanations for allegedly illegal insider trading, beyond the one possibility already discussed (trading for a reason other than the inside information). This is meant solely as a descriptive exercise; later on, the conclusion will try to link this back to the various legal muddles. Here we will be content to grapple with the "what were they thinking" question.

${ }^{21}$ For a discussion of the issue, see SEC v. Sargent, 229 F.3d 68 ( $1^{\text {st }}$ Cir. 2000). 


\section{A. Rational choice: Risks and benefits}

The first explanation is the simplest, and probably the most robust. Along the lines of the orthodox approach to the economics of criminality, we can simply say that to the person faced with an opportunity for insider trading, the benefits in terms of gains exceed the risk. Famously, James O'Hagan, the subject of the Supreme Court's misappropriation theory decision, was apparently motivated by the need to avoid detection of his own embezzlement of client funds from the law firm's accounts, which he was going to replace with the proceeds of the insider trading. $^{22}$ The benefits, presumably, are mainly monetary, though we could easily add other forms of utility such as thrill-seeking satisfaction, status enhancement, ego gratification, and the like.

The risks are impossible to assess with rigor. One can predict that if caught, the SEC will seek monetary recovery in the order of three times the gains from the trading, ${ }^{23}$ which would set up a fairly concrete decision structure. But there is also a real risk of criminal prosecution, with significant jail time upon conviction. In addition, there is ample collateral damage even from simple civil enforcement, including attorneys' fees that may not be covered by indemnification or insurance, career loss and other reputational sanctions, and so forth. Even more difficult to assess is the risk of detection. It seems to be common wisdom that the risk of detection is quite

${ }^{22}$ See United States v. O’Hagan, 139 F.3d 631 ( $8^{\text {th }}$ Cir. 1996) (on remand, noting evidence of theft from law firm client accounts).

${ }^{23}$ See Langevoort, supra note 2, at 8:4, 8:9. 
low, but it is hard for anyone to know for sure. There is ample evidence of price run-ups in advance of public announcements of major corporate events like M\&A transactions, but it is impossible to assess how much of this is illegal trading as opposed to information leakage, which (especially given the murky state of the law) may be lawful. ${ }^{24}$ The number of insider cases brought by the SEC in any given year is between fifty and seventy, plus a handful of criminal cases outside the Commission. One could reasonably conclude that the odds are strongly against detection.

A recent paper by Battacharaya and Marshall seeks to address the rational choice structure of insider trading enforcement by looking a set of high-ranking officers of public companies who have been found liable for insider trading. ${ }^{25}$ Their hypothesis is that "poorer" managers should be more heavily represented in the sample than "richer" managers, because the former have less to lose, career-wise, if their unlawful trading is detected. The data, however, rejects that hypothesis, leading the authors to suggest that insider trading may not be an entirely rational choice calculation.

${ }^{24}$ See Lisa Muelbroek, An Empirical Analysis of Illegal Insider Trading, 47 J. Fin. 1661 (1992).

${ }^{25}$ See Utpal Bhattacharaya \& Cassandra Marshall, Do They Do It for the Money?, 18 J. Corp. Fin. 92 (2012). A study of a sample of students indicates their impression, on average, that severity of penalties for insider trading is the primary deterrence factor. Joseph D. Beams et al., A Test of Deterrents to Insider Trading Using Importance Ratings, 8 Acct'g \& Pub. Int. 94 (2008). 


\section{B. Risk mis-estimation}

Because the risk estimation associated with an insider trading decision is so speculative, it is hard to assess its rationality. Later on, we will come back to how emotional impulses and other cognitive factors might bias this estimation. But before getting there, we should probably consider the possibility that people systematically underestimate the risk of detection, even if the risk is relatively low. In other words, do they perceive the risk to be even lower than it really is?

We can only speculate. The SEC and prosecutors bring publicity to bear on their cases in an effort to make it seem like detection is commonplace, and we cannot rule out that this campaign works to inflate the perception of likelihood of detection. On the other hand, it is likely that insider trading opportunities arise in settings (like M\&A work at an investment banking firm or law firm) where there are direct or indirect observations of likely illegal trading, which if not detected by the authorities will probably bias the judgment as to likelihood downward (as well as increase the ego and status pressures to conform). In this sense, insider trading is likely to be viral, and if the probability of detection is indeed low as a statistical matter, the perception that people are getting away with it will seem especially high until an enforcement action hits close to home.

In any event, public knowledge of how insider traders are caught is relatively sparse (though maybe not in elite social and economic circles). Recent publicity about wiretaps and other criminal detection devices notwithstanding, most cases arise from backward induction from evidence of unusual stock price moves, although tips are another source. ${ }^{26}$ Thus it would not be

\footnotetext{
${ }^{26}$ See Langevoort, supra note 2, at 1:13-:15.
} 
foolish to assume that if one's trading was limited enough or disguised enough not to affect price, it could scarcely be detection, assuming reasonable cover-up efforts like trading through someone else's account. The flaw in this thinking is in assuming that no one else is trading contemporaneously on the same information. But if there are other insiders, tippees or followers, the warning bells at the SEC and FINRA may ring even if the person's own trading is fairly limited. And the data exists to find out who was trading in the right direction in the days or weeks before an announcement, with very sophisticated software that can identify clusters of trading or other factors to suggest connections among traders. From that it is just detective work, typically aided by "flipping" certain subjects of the investigation in order to have them reveal their sources, from which other contacts with that same source can then readily be identified.

\section{Cultural influences}

One of the standard critiques of the Becker model of criminality is that it underestimates the degree to which people will behave "appropriately" even in the absence of optimal sanctions because of an innate or socially constructed sense of what is right and wrong. In the social psychology literature, there are ample claims that at low levels of probability of detection (and assuming no truly draconian penalties) most people conform to expectations as to appropriate standards of what constitutes legitimate behavior. ${ }^{27}$ That is not the same as lawful behaviorsome forms of unlawfulness (e.g., moderate speeding on open highways) are deemed legitimate.

${ }^{27}$ See Mohammad Abdolmonhammadi \& Jahangir Sultan, Ethical Reasoning and the Use of Insider Information in Stock Trading, 37 J. Bus. Ethics 165 (2002). 
In addition, some legal rules do not have much social legitimacy, and so will carry little power in the absence of strong threats of punishment. Obviously, legitimacy varies in both larger and smaller cultures. Given the vigorous debates about whether insider trading is good or bad, one could reasonably predict that cynically viewing insider trading regulation as foolish or the product of special interest pressure would make it more likely that one would engage in unlawful trading. ${ }^{28}$

There is an interesting literature emerging that seeks to test the cultural legitimacy of insider trading restrictions on a society-wide basis. Survey evidence by Statman asked various university students and finance professionals around the world to react to a fact situation based on the O'Hagan case, mentioned earlier, in terms of whether his behavior was fair or acceptable. ${ }^{29}$ That it was not acceptable was the overwhelmingly commonplace judgment in the USA and the Netherlands, with only slightly more ambivalence in Australia and Israel. By contrast, in countries like India, Turkey, and Italy, roughly half the respondents rated the behavior as completely acceptable. (Some evidence also ties the incidence of insider trading to cultural variations as to risk tolerance. ${ }^{30}$ )

${ }^{28}$ See Joseph D. Beams et al., An Experiment Testing the Determinants of Noncompliance with Insider Trading Laws, 45 J. Bus. Ethics 309 (2003).

${ }^{29}$ See Meir Statman, Perspectives: Local Ethics in a Global World, 63 Fin. Analysts J. 32 (May-June 2007); Meir Statman, The Cultures of Insider Trading, 89 J. Bus. Ethics 51 (2009). ${ }^{30}$ See Bart Frijns et al., A Proclivity to Cheat: How Culture Influences Illegal Insider Trading, available at http://ssrn.com/abstract=1972585. 
This suggests that there could easily be cultural patterns to insider trading behavior at low levels of detection risk, simply because of differing views as to the legitimacy of the legal restraints. And of course broad social or cultural forces can easily be trumped by local ones, in certain markets, firms or lines of business. Cultural perception, say, at an investment banking firm that insider trading is harmless and a sign of economic connectedness could easily blunt the perception of wrongfulness that otherwise might exists fairly widely in a country like the USA among the more general population. ${ }^{31}$

D. Failure to understand (or properly apply) the law

To me, one of the most likely explanations for instances of insider trading is a failure by the trader or tipper to properly appreciate what the law is, or to apply the law to the facts accurately. The issues here fall into two related categories.

We have already seen some of the issues on which courts still have not agreed: the possession versus use disagreement, the precise meaning of "nonpublic," and the role of personal benefit in misappropriation cases, for example. The law of insider trading has evolved in a common law style, so that even a well-trained lawyer could not always give a confident answer as to what the prevailing legal standard is.

${ }^{31}$ See Donald C. Langevoort, Chasing the Greased Pig Down Wall Street: A Gatekeeper's Guide to the Psychology, Culture and Ethics of Financial Risk Taking, 96 Cornell L. Rev. 1209, 1215 (2011). 
But that problem is dwarfed by the relative indeterminacy of so many of the legal standards that are well established. The most obvious example is materiality, a subject that Joan Heminway has explored in some depth. ${ }^{32}$ Materiality refers to likely importance; in insider trading, it is a proxy for that which is important enough that a reasonable person would expect the market price to move upon discovery of the information, thereby creating a pre-discovery profit opportunity to exploit. To the insider or tipper, of course, that is only a prediction: the market reaction is observed only after the allegedly unlawful activity. Much of the time, the information in the insider's possession only suggests that there might be a significant event, without one yet having ripened into concrete reality. This is material if, looking jointly at the probability of occurrence and the magnitude of the impact, the expected value of the event is significant enough. ${ }^{33}$ By all accounts, these are hard calculations to make prior to the event (and as discussed below, are subject to a very different perspective when judged in hindsight).

Quite possibly, some insiders have no sound intuition of this, but rather assume that insider trading is about risk-free profits, which assumes something akin to certainty embedded in the secret. Even if not, insiders will often confront factual ambiguity that is not easy to assess. A fairly recent SEC enforcement action targeted mid-level managers at a railway company that was being sold. They were not privy to information about the sale, but gleaned the possibility from a variety of facts, including well-dressed people inspecting railway assets, unusual assignments to

${ }^{32}$ See Joan Heminway, Materiality Guidance in the Context of Insider Trading: A Call for Action, 52 Am. U. L. Rev. 1131 (2003).

${ }^{33}$ See Basic Inc. v. Levinson, 485 U.S. 224 (1988). 
provide lists of such assets, and the like. The district court let the case go forward on materiality, while expressing some discomfort as to the softness of the "facts" in defendants' possession. ${ }^{34}$

There are many other areas where similarly difficult or counter-intuitive issues lurk. When information is sufficiently "out there" to be public is hard to assess - quite a number of insiders have been the subject of enforcement proceedings even though information about the event was already in the newspapers at the time of their trading, because the SEC contends that what they knew was more certain that what the media was reporting. ${ }^{35}$ The issue of duty is also murky. How many people not deeply familiar with the law in this area would realize that it is permissible to trade on most kinds of information that your overhear some executives talking at a restaurant, but that it is not lawful to trade on similar information heard coming from an executive at, say, an Alcoholics Anonymous meeting? ${ }^{36}$

Without at this point passing judgment on insiders' excuses as to ignorance of the law, the murkiness of the inferences necessary to determine legality or not connects back to our discussion of perceptions of legitimacy as strong indicators of behavior when likelihood of detection is low. Where there are competing factual inferences-i.e., the trader can say that he is simply being smart, not cheating - the ability to construe the trading opportunity as legitimate goes up.

\footnotetext{
${ }^{34}$ See SEC v. Steffes, 2012 WL 3418305 (N. D. Ill. 2012).

${ }^{35}$ See SEC v. Mayhew, 121 F.3d 44 (2d Cir. 1997).

${ }^{36}$ Compare SEC v. Switzer, 590 F. Supp. 756 (W.D. Okla. 1984) with SEC v. McGee,
} Litig. Release 22288, March 14, 2012. 


\section{Psychological bias and insider trading}

To this point, by and large, we have been assuming that the decision to trade or tip is a matter of conscious deliberation, with all these factors - anticipated gain, risk of detection, cultural or moral legitimacy, and legal indeterminacy — all competing to determine the judgment about how to act. But to most research psychologists, that would be grossly simplistic.

Contemporary research on judgment and decision-making strongly suggests that the conscious portion of choice is just the proverbial tip of the iceberg, that what we are aware of is making a decision is often a poor representation of how or why the choice was made. The research is still evolving as to precisely how, when and why various factors (neurochemical, dispositional, situational) might dominate, but insights from cognitive neuroscience are increasing rapidly, including from a research subspecialty specifically devoted to economic and

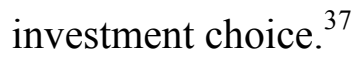

At the risk of oversimplification, the main idea here is that impulses like fear and greed will influence how a situation is perceived, greasing the pathway by which conscious deliberation follows the desire. In an interesting survey of the research for portfolio managers, William Bernstein writes:

Being evolutionarily ancient, the human limbic system does not look very different from that of frogs or reptiles. Located in the limbic system's front part, just behind each eye, is a pair of structures called the nuclei accumbens. Neuroscientists have

${ }^{37}$ E.g., Andrew W. Lo, Fear, Greed and Financial Crisis: A Cognitive Neuroscience Perspective, in J.P. Fouque \& J. Langsam, eds., Handbook on Systemic Risk, forthcoming. 
determined that these tiny paired structures respond most intensely to the anticipation of reward (be it culinary, sexual, social or monetary) as opposed to the reward itself, and that this anticipation response can be rapidly conditioned by just a few preceding rewards. To label the nuclei accumbens our "greed center" is not too much of an exaggeration. They activate each time an investor turns on CNBC television at 9:20 a.m. during a bull market and connects Maria Bartiromo's smiling, winsome visage with his or her escalating net worth, or when a banker contemplates a risky but potentially profitable loan transaction. ${ }^{38}$

Such activation influences both what is paid attention to, and how situational variables are interpreted. In that sense, this process of "motivated reasoning" readily links back to each of the explanations for insider trading that we have considered thus far. ${ }^{39}$ As to risk perception, for example, even without motivation, we can misconstrue baseline risk simply because of the paucity of information about enforcement. But motivation can then build on this, turning the sense in which colleagues have (or seem to have) taken advantage of inside information into an artificial feeling of almost no risk. At the same time, of course, that same observation may increase the desire as well: as Charles Kindleberger perceptively wrote, nothing disturbs a person's judgment and well-being more than watching a friend get rich. ${ }^{40} \mathrm{We}$ can also see easily

${ }^{38}$ William Bernstein, Of Laws, Lending and Limbic Systems, 66 Fin. Analysts J. 17, 19 (Jan.-Feb. 2010).

${ }^{39}$ E.g., David M. Bershoff, Why Good People Sometimes Do Bad Things: Motivated Reasoning and Unethical Behavior, 25 Personality \& Soc. Psych. Bull. 28 (1999).

${ }^{40}$ Charles Kindleberger, Manias, Crashes and Panics 15 (4 ${ }^{\text {th }}$ ed. 2000). 
enough how desire will also influence the perception of legitimacy. What is fair is very much in the mind of the beholder, and can represent little more than the rationalization of wants. ${ }^{41}$

But it is the indeterminacy of the law, and factual inferences relating thereto, where particularly powerful greasing can take place. The mind will try to find ways to construe the situation so as to invoke real or imagined excuses and safe harbors. A director learning bad news about his or her company may come to think that a decision to sell was actually made some time ago based on other circumstances, but just delayed - the inside information is not really being "used." Uncertainty might be inflated to diminish the perception of materiality; imagining that others must know (and be acting) on the information will blunt the inference of non-publicness.

These are just inferences from the psychological research, of course. We cannot study the mind of the insider trader directly. ${ }^{42}$ But we have some anecdotal glimpses to draw from, the most celebrated of which is the story of Martha Stewart's troubles stemming from her sales of stock in ImClone in December 2001. Stewart was a friend an acquaintance of the founder of

${ }^{41}$ For a book-length treatment of these kinds of processes generally Max H. Bazerman \& Ann E. Tenbrunsel, Blind Spots: Why We Fail to Do What's Right and What to Do About It (2011).

42 There are occasional "mea culpas" from convicted insider traders, trying to explain their thinking — often by reference to pervasive rationalizations or stupidity. Dennis Levine, one of the first major insider traders to be exposed, has offered one such account. See Dennis B. Levine, The Inside Story of an Inside Trader, available at http://techsci.msun.edu/wilke/BUS\%20Courses/BUS\%20405/Spring\%2005\%20Pages/Finance\% 20and\%20Accountancy/Insider\%20Trading/Inside\%20Story/Inside\%20Story.pdf. 
ImClone, and they shared the same stockbroker (Bacanovic) at Merrill Lynch. They all knew that ImClone was soon about to receive a highly significant ruling from the FDA about an important drug under development. On December 27, she received a call from Baconovic's assistant while on a holiday flight, telling her essentially that ImClone was trading down and the Waksal's were selling their stock. She immediately told the broker's assistant to sell her stock as well, and just avoided a loss of approximately $\$ 45,000$ from so doing.

On its face, this was at least a reckless decision. Stewart sold the stock in a highly visible account at a well-known broker-dealer as a result of information at least closely connected to the top levels of management at ImClone. She was reasonably familiar with the prohibition against insider trading, though perhaps not all its nuances. Even conceding some difficult legal issues as to whether she could take advantage of this information or not, the risk should have been palpable. So what was she thinking?

This takes us to Stewart's thought-process that day, and here we can draw on some background facts provided by behavioral finance scholar Meir Statman. ${ }^{43}$ Stewart was not a very

${ }^{43}$ The specifics facts recounted here are drawn from Meir Statman, Martha Stewart's Lessons in Behavioral Finance, 7 J. Inv. Consulting 1 (2005). For an elaboration, from which much of the following analysis is taken, see Donald C. Langevoort, Reflections on Scienter (and the Securities Fraud Case Against Martha Stewart that Never Happened), 10 Lewis \& Clark L. Rev. 1 (2006). Interesting commentary on her trial is found in Jeffrey Toobin, A Bad Thing: Why Did Martha Stewart Lose?, The New Yorker, March 22, 2004, at 61, and Jeanne L. Schroeder, Envy and Outsider Trading: The Case of Martha Stewart, 26 Cardozo L. Rev. 2023 
successful investor. She had a portfolio loaded with technology stocks (ImClone, in the biotech field, was one), and was badly hurt by the technology sector sell-off that occurred in 2000 and 2001. Her portfolio value (excluding MSLO) declined from $\$ 4,530,730$ in June 2000 to $\$ 2,510,973$ in December 2001.

What was most notable is how reluctant she was to sell her stocks, which may connect to a tendency often noted in the behavioral finance literature. Stewart was regularly favored with IPO allocations, meaning that she was able to buy the stocks at a deep discount to likely nearterm market values. Whether or not they "flip" immediately, many investors take their profit in the near-term. Stewart did not, holding the shares through expectedly dramatic price increases and then, later on, through the bursting of the tech stock bubble. She thus managed to lose money even having started in such an extraordinarily favorable position.

Whose fault this was is not clear; Stewart apparently blamed Bacanovic and Merrill. In any event, Bacanovic met with Stewart in mid-December to urge her sell her "loss" stocks before the end of the year to offset against taxable income. They discussed each of the holdings, including ImClone, and Stewart finally sold off all twenty-two of her loss stocks on December 21 and 24 for a combined loss of $\$ 1,037,874$. Because ImClone was one of her few profitable stocks (and by far her most profitable), she held onto it. She had bought ImClone at $\$ 16$, and as of mid-December had a gain of some $\$ 186,000$. Crucially, Stewart said that this selling "made her stomach turn," an interesting psychological point. In fact, the tax losses were quite valuable given Stewart's other income. However, having to finally admit defeat and take the losses-

(2005). For a book containing various perspectives on the case, see Joan MacLeod Heminway, Martha Stewart's Legal Troubles (2007). 
notwithstanding such potential for gain a year or two earlier-was devastating to Stewart's ego, and generated a good deal of anger and regret. So far as her investments were concerned, Stewart was in late December in an emotionally depressed state.

Then, on December 27, just three days after the stomach-turning sales were done, she got the phone call from Bacanovic's assistant indicating that her only remaining winner, ImClone, was also about to implode. One can at least appreciate what was no doubt a very emotional response-not this one, too. If she had a chance to avoid this loss by selling before the market adjusted, such risky behavior can at least be placed in context, ${ }^{44}$ though it certainly wouldn't be a defense to insider trading.

But what about the legal risk? Consider what Stewart learned from Bacanovic's assistant. Initially, there were two bits of information in the phone message - that the Waksals were selling and that Bacanovic expected the price to decline. She called the broker's assistant and learned one more fact - that the price had already fallen a good bit. My suspicion is that (especially in an angry and emotional state) she could easily construe this to mean that adverse information had already reached the market, and the big institutions were starting to bail out. She did not want to be left behind, again.

As to the Waksals' selling, I suspect that she construed this as the Waksals and much of Wall Street. In fact, it is hard to imagine (especially to a former stockbroker) that she would assume that she was being told that the Waksals were selling illegally-which would be the case if the information had not yet made it to the market. Illegal sales by senior executives do not usually occur in an unconcealed fashion through a reputable broker. Again, the more likely

\footnotetext{
${ }^{44}$ See Statman, supra note 43.
} 
inference is that word about Erbitux had become public and that the Waksals were joining the crowd.

Whether this is a successful defense as a matter of law is a bit murky. As Rule 10b5-1 shows, the SEC prefers a simplified state of mind inquiry, and could claim that even if the foregoing were true (1) Stewart still had one piece of information that the rest of the world did not, received from a private source in arguable breach of fiduciary duty; (2) under these circumstances, she recklessly failed to ascertain the state of public knowledge before selling; and (3) that information does not become public until it is fully internalized by the market (i.e., trading by the smart money is not enough if the price is still adjusting).

But I doubt that under the emotional pressure prompting so many psychologically potent forces-loss aversion, regret, and stomach-turning shame-she would have construed the situation with such acuity. Her mind wanted to sell that stock, and the construal gave her permission to do so. Others were selling, so she could, too. Bad judgment, perhaps, but not all that surprising psychologically. Like so many bad judgments by those with high ego and selfesteem, it generated a poorly-executed cover-up, which is what actually landed Martha Stewart in jail.

III. Connecting the explanations and the law

Our remaining task in this Chapter is to connect these explanations to the legal conundrums discussed in the first part. Obviously, when insider trading is a deliberate choice to assume the risk of detection because of the expected utility in terms of money, thrill, ego or whatever, the explanations add little. The penalty structure of USA insider trading law is built on 
the implicit assumption that these cases are about greed, and can be deterred by getting the right mix of sanctions and detection resources. We might not have the optimal mix, but it would not be because we misunderstand what is happening. If anything, stopping here underscores the idea that "misuse" of inside information is what we are trying to reach, so that courts that prefer that formulation of the law have it right.

That there might well be individual or cultural legitimation of insider trading at work when someone chooses this same risk might alter the characterization of what is going on-there is a rejection rather than an appreciation of wrongdoing — but that is not a particularly troubling legal issue, either. Similarly, misconstrual of the law generally is met with the response that ignorance is no excuse. It does get harder, however, when misconstruals go to facts (like materiality or non-publicness) rather than law (duty). Scienter does suggest that there must be some contemporaneous appreciation of both significance and secrecy to which eyes are being shut. As suggested in our discussion of the Martha Stewart case, I think there was a plausible argument that she thought— too hastily, perhaps, but without conscious doubt—that word of the FDA action had become public knowledge at least within sophisticated trading markets, which could be a defense to liability. Here the stress turns to recklessness, and the difficulties in drawing the line between deliberate indifference to a known risk and conduct that, in hindsight at least, is hard to explain. That said, if insider trading law is meant to address deliberate exploitation of entrusted information, extending liability too far in the direction of recklessness is unnecessary to carry out the law's expressive function.

Indeed, one of the least understood issues in insider trading law today is the role of recklessness. What would we mean by reckless insider trading? One can readily imagine a case where an executive suspects good or bad news at the time he directs a trade without being sure 
and proceeds to buy or sell anyway, but this type of case need not reach for recklessness because the very set of facts that made him aware of the risk would probably be material nonpublic information. A possession rather than use standard would no doubt be helpful to the enforcers in a case such as this, but that is simply a practical advantage in dealing with uncertainty, one of the standard arguments for a possession test.

When we turn to tipping, however, we see more room for argument. Suppose a person passes on information to another without actually intending to make a tip (much less for personal benefit), but under circumstances where there is a cognizable risk that trading will result. The personal benefit test makes enforcement under the classical theory hard here, but-under substantial SEC prodding, as we saw earlier - a number of courts say that test does not apply in misappropriation cases. Probably, the main effect of this line of authority is to open up the possibility of reckless tipping. There are a number of cases that might fit this category, most notably those involving employees of magazine printers who sold advance copies of the magazines (e.g., Business Week) to persons who wanted to know what companies would be mentioned favorably, in order to profit from the anticipated market rise. ${ }^{45}$ It was not clear that the employees necessarily knew of this intent, and there were other reasons the purchasers might have wanted advance copies besides the intent to trade. Here, however, we still have a solid "greed" story.

As we turn to the possible psychological explanations for trading or tipping, the law's standards seem more naive. For example, a standard that requires a fact-finder to determine that the receipt of the inside information "caused" the trade assumes an overly simple model of

\footnotetext{
${ }^{45}$ See United States v. Falcone, 257 F.3d 226 (2d Cir. 2001).
} 
decision-making. Insiders can easily come to believe that they really did have other reasons for trading, and apart from rough assessments of credibility, fact-finders have little to guide them in determining if this is right. The Second Circuit, quoted earlier, was reasonably sophisticated in its skeptical assessment of this task. ${ }^{46}$

On the other hand, a standard of "awareness" fares poorly from a psychological standpoint, too. If there is a punch line to the research we have described, it is that much of what is crucial to behavior occurs outside of awareness, with awareness generating something of a false consciousness. That is to say, some subset of what we treat as insider trading — some, but by no means all— probably is not experienced by the individual in question as awareness that any material nonpublic information is being exploited. A hard question in the law of insider trading is how to characterize the behavior of someone who we think should have known better but may have lacked the contemporaneous appreciation ordinarily associated with scienter. Once again, this is work usually done by invoking recklessness, which is not a particularly good fit with what we mean by insider trading.

However, we shouldn't obsess too much on all this. All these scienter labels are attached by judges and jurors acting outside the mind of the defendant, in hindsight. ${ }^{47}$ The uncertainties and ambiguities that might have clouded the mind of the defendant at the time will not be at work in their own minds as they pass judgment. The certainty of the money made by the defendant will be particularly salient, and the tendency to explain behavior in terms of individual

\footnotetext{
${ }^{46}$ See U.S. v. Teicher, 987 F.2d 112 (2d Cir. 1993). .

${ }^{47}$ See Mitu Gulati et al., Fraud by Hindsight, 98 Nw. U. L. Rev. 773 (2004).
} 
disposition - referred to by psychologists as the fundamental attribution bias - means that the fact-finder will interpret the story more readily in terms of intentionality.

None of this is necessarily unique to the law of insider trading - all forms of law that depend on relatively exacting state of mind standards suffer if they ask fact-finders to determine liability through simplistic labels like intent or recklessness. But insider trading is somewhat unique because, for better or worse, we have made a level of evil disproportionate to its actual economic impact. If insider trading prosecutions are intended as little morality plays in the name of promoting a brand that is about fair play in the securities markets, as I suggested at the outset, we should worry at least a little about what really was in the mind of the trader or tipper unless we are just making examples of them for public consumption. 